\title{
Key Success Factors for Critical Chain Project Management (CCPM) and 4D Building Information Modeling (BIM) for Improving Time Performance in Basement Work on 5 Layers of High-rise Residential Buildings in Indonesia
}

\author{
Truman Sinaga $^{1}$ \& Albert Eddy Husin ${ }^{2}$ \\ ${ }^{1-2}$ Departement Master Program of Civil Engineering \\ Mercu Buana University \\ Jakarta Indonesia
}

\begin{abstract}
Referring to data released by The Skyscrapper Center in 2020, during the period 1960 - 2020 there was a rapid increase in the construction of buildings with a height of more than 150 meters around the world. The increase in high-rise residential buildings or high rise buildings according to the global competitiveness report data from 2014 - 2020 will be the largest growth country in the construction sector with an average total growth value of $6.3 \%$ so that engineers - architecture carry out and make project management engineering from the initial project phase to the project completion phase and the increasing complexity of problems in the planning process to the management of high-rise residential buildings. The need for housing in Indonesia, especially in big cities, is high and the limited availability of land causes prices to increase, so that investment in residential high rise buildings is growing rapidly. The high demand for the community is directly proportional to the increase in the number of residential building construction for high-rise buildings. Building construction is expected by service providers to be completed on time without delay according to their planning. However, in the implementation of development there are problems that cause delays in its implementation. The delay that occurs can be from internal, external and weather factors. For this reason, this research will discuss the key success factors of critical chain project management (CCPM) and 4D building information modeling (BIM) for improving time performance on the basement work of 5 layers of high-rise residential buildings. To obtain the key success factors, the researchers used the SPSS (Statistical product and service solutions) tool. From the results of this SPSS, the researchers found 10 key success factors, namely 1. Project identification against time, 2. Basement design complexity, 3. Effect of project buffers, fedding buffer, buffer resources, 4. Accuracy of document design, 5. Scheduling and Simulation, 6. Logical relations of activities, 7. Policy and government support, 8. Top down methods, 9. Land conditions, and 10. Eliminating safety time. The 10 key success factors are expected to reduce delays in the implementation of development.
\end{abstract}

Key Words: Critical Chain Project Management, BIM, Basement work, SPSS

\section{INTRODUCTION}

The increase in high-rise residential buildings or high rise buildings according to the data from the global competitiveness report from 2014 - 2020 will be the largest growth country in the construction sector with an average total growth value of $6.3 \%$ so that engineers - architecture carry out and make project management engineering from the initial project phase to the project completion phase and the increasing complexity of problems in the planning process to the management of high-rise residential buildings, in Figure 1.1 is a graph of the estimated growth of the construction sector in 3 countries in Asia for the period 20142020 below: 


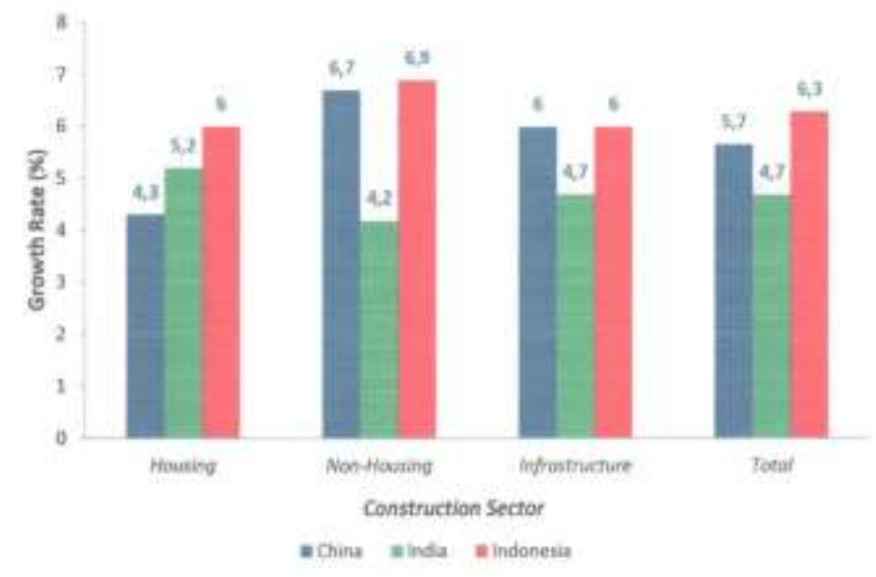

Figure 1.1 Estimated Growth of the Construction Sector in 3 Countries in Asia for the 2014-2020 Period [1]

With this large investment potential, investors will demand fast and cost effective time performance. For large-scale projects with a very large number of activities and complex dependencies / linkages between activities. Scheduling becomes complexity and very important so that activities can be carried out efficiently. Delays are common in construction projects. The delay in construction projects is caused by many factors. One of them is time inefficiency caused by errors in estimating the time needed to complete the project at the planning stage [2]. According to [3] One of the factors causing the delay is ineffective planning and scheduling by the contractor. One of the efforts to anticipate the delay in the duration of construction activities is to optimize the duration of the activities. In the field of construction project management, currently developing a new project scheduling method that is used in dealing with uncertainty in project completion. This method is known as Critical Chain Project Management (CCPM). Critical Chain Project Management (CCPM) optimizes buffer feeding and project buffers (additional time) in each activity to avoid untimely project scheduling by linking work relationships, resource constraints, safety time and eliminating waiting times and controlling safety time at each work so that you get the optimization of the schedule. According to [4] Simulation and visualization of 4D BIM can increase efficiency in the construction project planning process and 4D Simulation in terms of visual control is $40 \%$ higher than conventional planning. The 4D BIM can identify overlapping activity and analyze the level of risk for schedule overlap problems [5]. With the above background, research was carried out on the key factors of success in critical chain project management (CCPM) and BIM 4D in the basement work of 5 layers of high-rise residential buildings.

\section{THEORETICAL BASIS}

\subsection{Critical Chain Project Management (CCPM)}

The Critical Chain Project Management (CCPM) method was introduced by Dr. Eliyahu Goldratt in 1997, with Theory of Constraints (TOC) has been applied as a project management strategy. The Theory of Constraints (TOC) method is a competent approach to managing project risk, the approach is as follows:

1. Removing the hidden safety in the duration of the activity to protect the activity from starting too late which is called student syndrome.

2. Preventing pretense busyness by staff called Parkinson's Law

3. Prevents late completion of activities due to murphy's law.

Critical Chain Project Management is defined as the longest chain of interrelated events, where the interrelationships with each other lie in interconnected work or resources. [6]. The requirements in this Critical Chain Project Management method are the absence of multitasking, Student's Syndrome, Parkinson's law, As late as possible, eliminating hidden safety and moving it in the form of a buffer behind the project, and focusing on the final project completion. The buffer management methodology is used to prioritize jobs with constraints on the availability of resources which cause delays in implementation in construction projects.

\subsection{Introduction to Critical Chains}

The development of the critical chain is a method problem and cannot be ruled out [7]. There are four steps to identifying the critical chain in a project [8] namely: 1. Allocating the duration, 2. Advancing the activity, 3. Eliminating excess resource allocation, 4. Setting the buffer in place at the end of the duration. The difference in activity between the traditional Critical Peth Method (CPM) and Theory of Constraints (TOC) is as shown in Figure 1.2 below: 
International Journal of Engineering Research And Advanced Technology, Vol.7 (4), April -2021

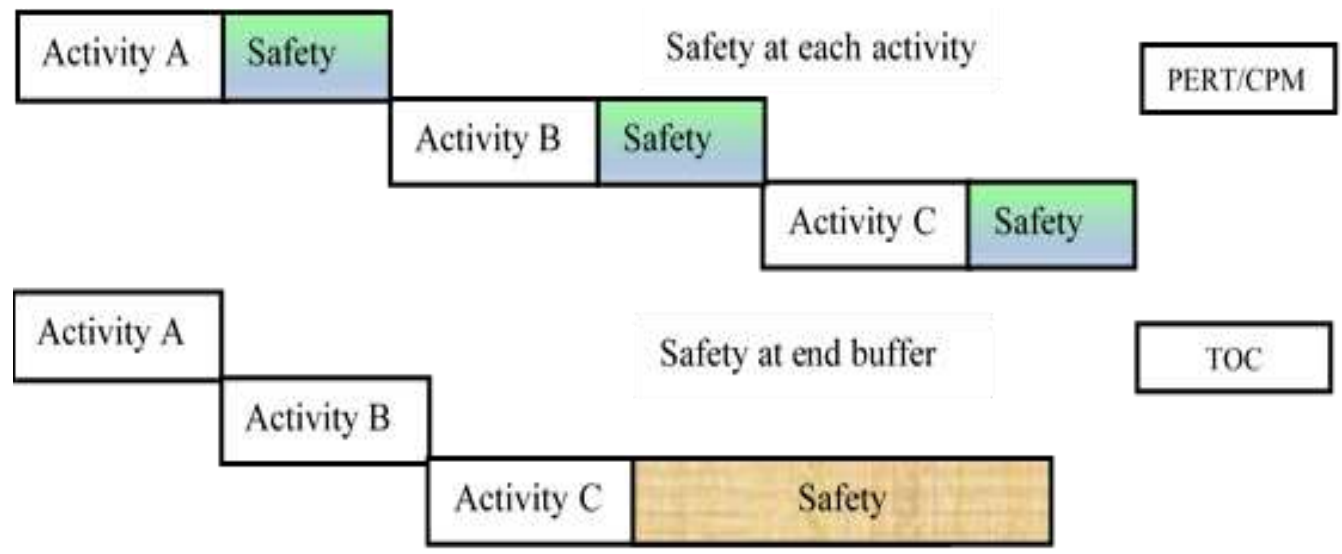

Figure 1.2 PERT / CPM and TOC comparison [9]

\subsection{Project Buffer dan Feeding Buffer}

Manage projects with Critical Chain Project Management (CCPM) using a time buffer, essentially Theory of Constraints (TOC) and provides simple tools to monitor projects and set realistic deadlines [10]. and is increasingly used in construction scheduling and its methods have undergone a number of refinements and existences [11]. The average task duration in the Critical Chain Project Management (CCPM) method instead of the duration with the safe time and between the two types of duration on each activity in the critical chain will be assigned to the end of the project as a project buffer (shown in Figure 1.3). This buffer is for trying to determine the completion date. Realization Execution of the project must be in excess of one chain so the CCPM predicts a buffer to protect this chain from delays. These buffers are called feeding buffers (buffer feeding in Figure 1.3) and are placed where non-critical chain activity joins the critical chain. Finally, these buffers protect critical chain activity from disruption and delay start [12]. Buffers play a key role in CCPM [13] and Finally, these buffers protect critical chain activity starting from delay interruptions [14].

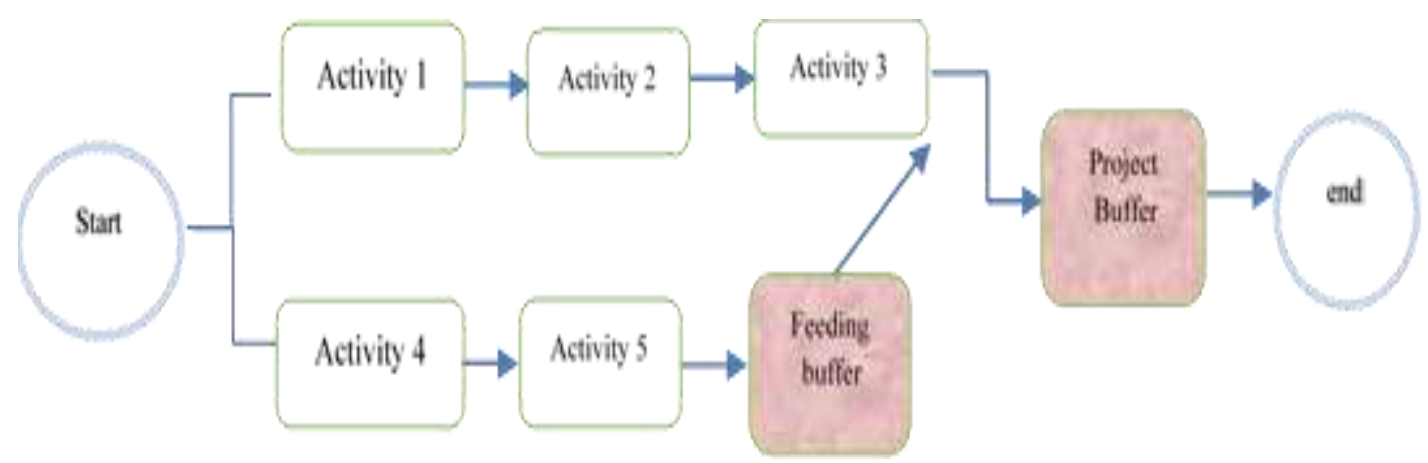

Figure 1.3 Project buffer and feeding buffer [15]

Take into account any defenses that may exist between activities, because all require the same resources [16] and the square root of the sum of the squares of this difference for each activity is then used as a buffer [17] and according to [18] this advantage becomes clearer as the size of the problem increases.

\subsection{Building Information Modeling (BIM) 4D}

The development of Building Information Modeling (BIM) in Indonesia is marked by an initiative from the government under the Ministry of Public Works and Public Housing which has launched the Indonesian digital construction Roadmap program through the application of Building Information Modeling (BIM) technology to increase productivity in construction projects, especially projects - government projects as shown in Figure 1.4 below : 


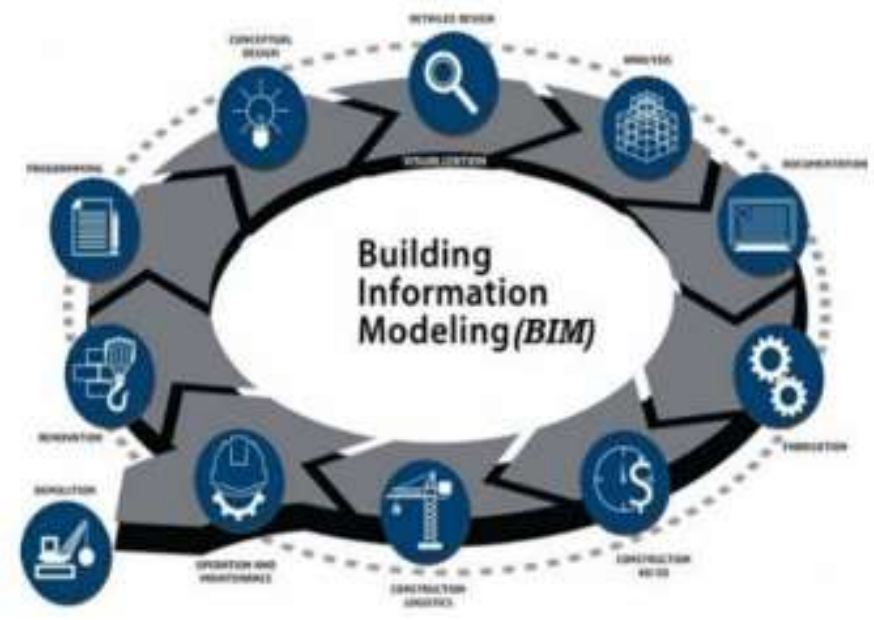

Figure 1.4 Roadmap for Building Information Modeling (BIM) Indonesia 2017-2024[19]

The use of Building Information Modeling (BIM) modeling in high-rise residential building systems in conjunction with collaborative design teams is one of the most useful approaches in achieving cost-effective and high-quality design results. actual physical construction and an approach to building design, management and cutting costs significantly and in terms of time. Building Information Modeling (BIM) has the implication of giving change, encouraging the exchange of 3D virtual models between different disciplines, so that the information exchange process becomes faster and affects construction implementation.[20] and the application of BIM will make cost and time efficient Implementation of the project because data designers usually use a variety of design tools to complete their own design tasks with respect to the different characteristics of these disciplines [21].

\subsection{Basement}

Basement is a vertical downward development that creates an underground space (Basement) which is part of the building.

\subsection{Types of Work in the 5 Layer Basement}

Planning and Implementation Methods in high-rise residential buildings for basement work have specific characteristics, in particular on work methods and application of implementation technology. Some specific things are the order of work, type of work, vertical transportation activities, work safety, location limitations, and ground water [22]. The types of work in the basement generally consist of: 1) Bored Pile work, 2) Capping beam work on bored pile concrete, 3) Earth excavation work, 4) Mechanical earth removal, 5) Ground Angkur work, 6) Waller work Beam (if any), 7) Concrete wall work / retaining wall, 8) Work and Tie Beams, 9) Basic concrete floor work, 10) Beam and column concrete work, 11) Slab deck work or concrete floors 1-4 and ram vehicles, 12) Emergency staircase work, pit lift work, 13) multipurpose building work, 14) steel reinforcing work or ironwork, 15) mechanical electrical work, 16) plumbing work, 17) dewatering work, 18) fire safety work and 19) KM / WC work.

\subsection{Scheduling in Construction Planning}

Scheduling is called scheduling is the allocation of time to carry out the completion of an activity properly and correctly will result in cost efficiency. Rework caused by design errors resulted in an increase of $5-20 \%$ of the total contract value [23] so that if the process of scheduling activities in each relationship between activities is made in detail and detail to assist the implementation of project evaluation. Construction project planning includes the process of determining the project scope, formulating the structure and project hierarchy, selecting the type of construction technology and method, formulating activities, estimating the required resources and the duration for each activity and identifying the linkages between activities.

\section{RESEARCH METHODOLOGY}

This research process contains a research flow from the beginning to finding a hypothesis to answer the problem formulation by conducting scientific research, where in the process there are stages / sequences that are adjusted to the research framework that has been compiled in the form of a flow chart. The flow chart is prepared based on the formulation and research objectives to be achieved by referring to the project feasibility study [24]: 
International Journal of Engineering Research And Advanced Technology, Vol.7 (4), April -2021

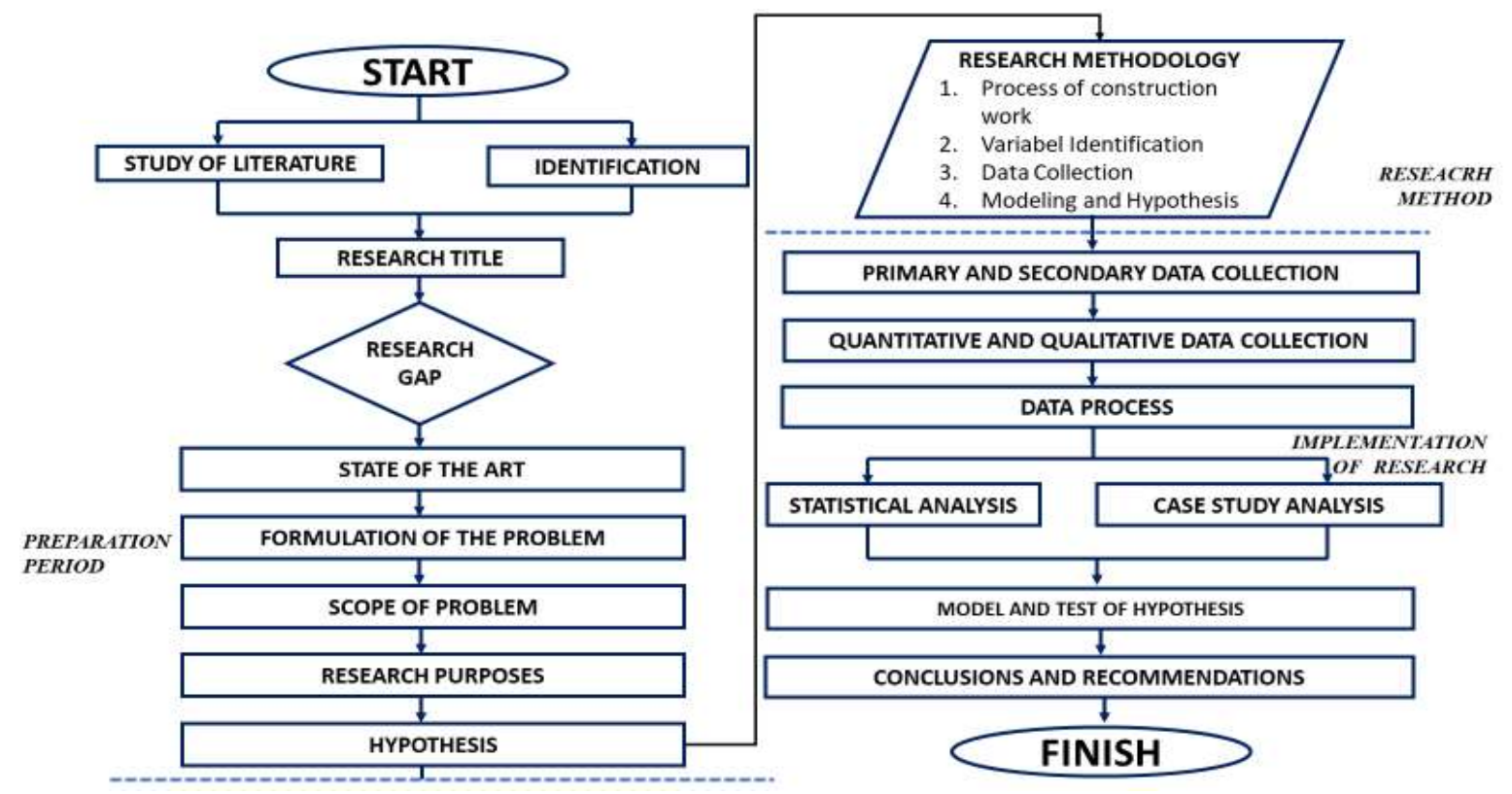

Figure 1.5 Research Flow

From this research flow data can be used to process and analyze data, in order to get the results that are expected. From this research can streamline the performance of the implementation of the construction of high-rise residential buildings on a 5-layer basement work.

\subsection{Variable Identification}

In this case the researcher took 1 (one) main variable to get the efficiency and accuracy of time as the independent variable, and 3 (three) variables as the dependent. The variables are:

Independent Variable : X1 = Critical Chain Project Management

$$
\begin{aligned}
& \text { X2 = Building Information Modeling (BIM) 4D } \\
& \text { X3 = Basement } 5 \text { layers }
\end{aligned}
$$

Dependent Variabke : Y1 $=$ Time

Identification of sub-variables related to project time performance consists of 4 variables, namely Critical Chain Project Management, 4D Building Information Modeling (BIM), Basement and Time. The number of respondents used in this study is 70 respondents. The following are the key success factors in increasing time:

\begin{tabular}{|c|c|c|c|c|}
\hline VARIABLE & MAIN FACTOR & \multicolumn{2}{|r|}{ SUB FACTOR } & REFERENCE \\
\hline \multirow{5}{*}{ 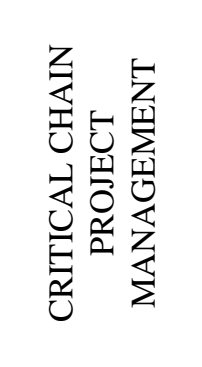 } & \multirow{5}{*}{$\begin{array}{c}\text { CRITICAL } \\
\text { CHAIN METHOD }\end{array}$} & 1 & Faster turnaround time & Ryan Ramanda, 2019 \\
\hline & & 2 & Minimizes project duration & Mohamad Aulady,2016 \\
\hline & & 3 & Determine the critical project path & Ryan Ramanda, 2019 \\
\hline & & 4 & $\begin{array}{l}\text { Steps for design of the CCPM } \\
\text { schedule }\end{array}$ & Mona P. Prajapati, 2017 \\
\hline & & 5 & Utilization of CCPM software & $\begin{array}{l}\text { Leonarda Valikoniene, } \\
2014\end{array}$ \\
\hline
\end{tabular}

Table 1.1 Key Success Factors 
International Journal of Engineering Research And Advanced Technology, Vol.7 (4), April -2021

Table 1.1 Key Success Factors

\begin{tabular}{|c|c|c|c|c|}
\hline VARIABLE & MAIN FACTOR & \multicolumn{2}{|r|}{ SUB FACTOR } & \multirow{2}{*}{$\begin{array}{c}\text { REFERENCE } \\
\text { Lisa M Repp }\end{array}$} \\
\hline \multirow{14}{*}{ 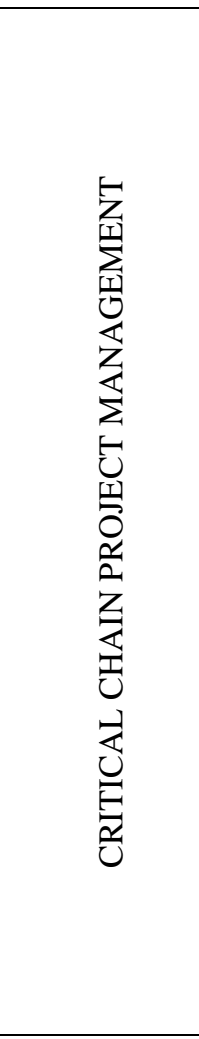 } & \multirow{6}{*}{$\begin{array}{l}\text { CRITICAL } \\
\text { CHAIN METHOD }\end{array}$} & 6 & $\begin{array}{c}\text { Determination of human } \\
\text { resources }\end{array}$ & \\
\hline & & 7 & Schedule planning \& monitoring & Lisa M Repp. \\
\hline & & 8 & $\begin{array}{l}\text { Schedule planning, monitoring, } \\
\text { and controlling solution }\end{array}$ & Lisa M Repp. \\
\hline & & 9 & $\begin{array}{c}\text { Eliminating Student Syndrome \& } \\
\text { Parkinson Law }\end{array}$ & $\begin{array}{l}\text { Ghaffari \& M. W. } \\
\text { Elmsley, } 2015\end{array}$ \\
\hline & & 10 & Commitments on time schedule & $\begin{array}{c}\text { Leonarda Valikoniene, } \\
2014 \\
\end{array}$ \\
\hline & & 11 & Real time project monitoring & $\begin{array}{c}\text { Leonarda Valikoniene, } \\
2014 \\
\end{array}$ \\
\hline & & 12 & Defines and defines buffers & Mohamad Aulady,2016 \\
\hline & & 13 & Identify the project against timing & $\begin{array}{c}\text { Mastura Labombang, } \\
2011\end{array}$ \\
\hline & & 14 & $\begin{array}{l}\text { Effect of Project buffer, fedding } \\
\text { buffer, buffer resource }\end{array}$ & Mona P. Prajapati, 2017 \\
\hline & BUFFER TIME & 15 & Eliminates safety time & Mohamad Aulady,2016 \\
\hline & & 16 & Risk Management & $\begin{array}{c}\text { Ghaffari \& M. W. } \\
\text { Elmsley, } 2015 \\
\end{array}$ \\
\hline & & 17 & Understanding the stages of work & Lisa M Repp. \\
\hline & & 18 & Eliminates safety time & Repp, 2012 \\
\hline & & 19 & Limited resources & Repp, 2012 \\
\hline \multirow{18}{*}{ 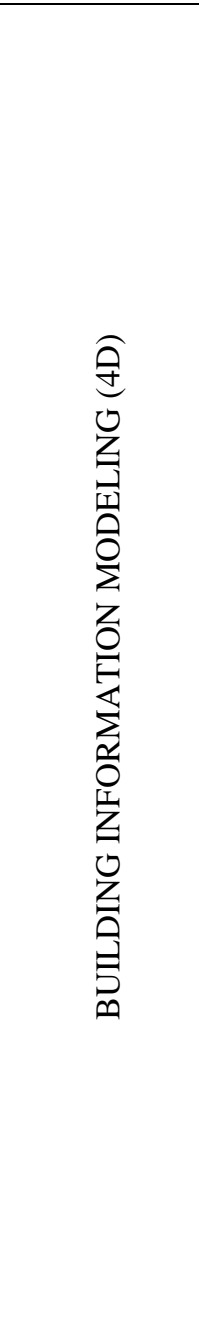 } & \multirow{11}{*}{$\begin{array}{l}\text { CONSTRUCTION } \\
\text { STAGE }\end{array}$} & 1 & $\begin{array}{c}\text { Effective communication and } \\
\text { coordination among the project } \\
\text { team }\end{array}$ & $\begin{array}{l}\text { Paul Chinowsky (ASCE), } \\
2010\end{array}$ \\
\hline & & 2 & Scheduling and simulation & Julie Jupp, 2017 \\
\hline & & 3 & Document design accuracy & Syal, 1992 \\
\hline & & 4 & Activity logical relationships & $\begin{array}{l}\text { Paul Chinowsky (ASCE), } \\
2010 \\
\end{array}$ \\
\hline & & 5 & Government policy and support & Thomas C. H, 2020 \\
\hline & & 6 & Use of BIM software tools & Thomas C. H, 2020 \\
\hline & & 7 & Work flow / work stages & Julie Jupp, 2017 \\
\hline & & 8 & $\begin{array}{c}\text { Determine project completion } \\
\text { constraints }\end{array}$ & Syal, 1992 \\
\hline & & 9 & Identify the project success cycle & $\begin{array}{l}\text { H. Randolph Thomas } \\
\text { (ASCE) } 2007\end{array}$ \\
\hline & & 10 & Develop a project strategy & $\begin{array}{l}\text { H. Randolph Thomas } \\
\text { (ASCE) } 2007\end{array}$ \\
\hline & & 11 & Develop the project layout & $\begin{array}{l}\text { H. Randolph Thomas } \\
\text { (ASCE) } 2007\end{array}$ \\
\hline & \multirow{7}{*}{ PEMODELAN 4D } & 12 & Duration of project activities & Gledson, 2017 \\
\hline & & 13 & $\begin{array}{c}\text { Simulation of the construction } \\
\text { process }\end{array}$ & $\begin{array}{l}\text { P. Ballesteros-Pérez } \\
\text { (ASCE) } 2020\end{array}$ \\
\hline & & 14 & $\begin{array}{l}\text { Equipment modeling in the work } \\
\text { environment / site }\end{array}$ & $\begin{array}{l}\text { Leni Sagita Riantini, S.T., } \\
\text { M.T., Ph.D. }\end{array}$ \\
\hline & & 15 & $\begin{array}{l}\text { Modeling \& lay out during the } \\
\text { construction process }\end{array}$ & Julie Jupp, 2017 \\
\hline & & 16 & $\begin{array}{l}\text { Modeling and visualization of the } \\
\text { significance of environmental } \\
\text { impacts }\end{array}$ & Julie Jupp, 2017 \\
\hline & & 17 & Study the previous project plan & Julie Jupp, 2017 \\
\hline & & 18 & Templates and formats & PMBOK 6th Ed, 2017 \\
\hline
\end{tabular}


International Journal of Engineering Research And Advanced Technology, Vol.7 (4), April -2021

Table 1.1 Key Success Factors

\begin{tabular}{|c|c|c|c|c|}
\hline \multirow{3}{*}{ 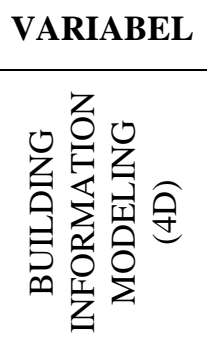 } & \multirow{3}{*}{$\begin{array}{c}\text { MAIN FAKTOR } \\
\\
\text { BUILDING } \\
\text { INFORMATION } \\
\text { MODELING (4D) }\end{array}$} & \multicolumn{2}{|c|}{ SUB FAKTOR } & \multirow{2}{*}{$\begin{array}{c}\text { REFERENSI } \\
\text { PMBOK 6th Ed, } 2017\end{array}$} \\
\hline & & 19 & Logistics modeling & \\
\hline & & 20 & 4D project modeling & $\begin{array}{c}\text { Cristina T. Pérez, } \\
2016\end{array}$ \\
\hline \multirow{13}{*}{ 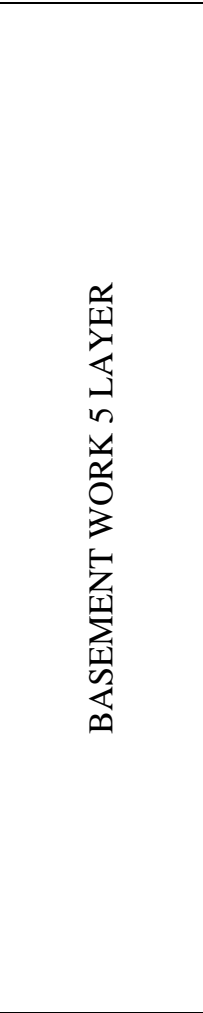 } & \multirow{7}{*}{$\begin{array}{l}\text { BASEMENT WORK } 5 \\
\text { LAYER PLANNING }\end{array}$} & 1 & Basic Engineering Design & $\begin{array}{c}\text { Jin Ouk Choi, Ph.D et } \\
\text { al, } 2020\end{array}$ \\
\hline & & 2 & $\begin{array}{l}\text { Early identification of } \\
\text { standardization }\end{array}$ & $\begin{array}{c}\text { Jin Ouk Choi, Ph.D et } \\
\text { al, } 2020\end{array}$ \\
\hline & & 3 & $\begin{array}{c}\text { Standardization feasibility } \\
\text { analysis }\end{array}$ & $\begin{array}{c}\text { Jin Ouk Choi, Ph.D et } \\
\text { al, } 2020\end{array}$ \\
\hline & & 4 & $\begin{array}{l}\text { Building design \& building } \\
\text { system management }\end{array}$ & $\begin{array}{l}\text { Ahmad Abdelrazaq, } \\
2012\end{array}$ \\
\hline & & 5 & $\begin{array}{c}\text { Decisions on design \& } \\
\text { construction }\end{array}$ & $\begin{array}{c}\text { Hadi Khabbaz et al . } \\
2019 \\
\end{array}$ \\
\hline & & 6 & Design & $\begin{array}{c}\text { G.M. Rotisciani et al, } \\
2016\end{array}$ \\
\hline & & 7 & Construction & $\begin{array}{l}\text { G.M. Rotisciani et al, } \\
2016\end{array}$ \\
\hline & \multirow{6}{*}{ IMPLEMENTATION } & 8 & $\begin{array}{c}\text { Project environmental } \\
\text { conditions }\end{array}$ & $\begin{array}{c}\text { Rara Dwi Noviarti, } \\
2018 \\
\end{array}$ \\
\hline & & 9 & Soil conditions & $\begin{array}{c}\text { Rara Dwi Noviarti, } \\
2018\end{array}$ \\
\hline & & PEMODELAN 4D & Bottom up method & Ho Steven, et al, 2014 \\
\hline & & 11 & Top down method & Ho Steven, et al, 2014 \\
\hline & & 12 & $\begin{array}{c}\text { Basement design } \\
\text { complexity }\end{array}$ & Han, 2012 \\
\hline & & 13 & Monitoring & $\begin{array}{l}\text { G.M. Rotisciani et al, } \\
2016\end{array}$ \\
\hline \multirow{10}{*}{$\sum_{i=1}^{\mu}$} & \multirow{10}{*}{ IMPLEMENTATION } & 1 & The weather is not fixed & Smarghandi 2016 \\
\hline & & 2 & Subcontractors & Smarghandi 2016 \\
\hline & & 3 & Lack of material & Smarghandi 2016 \\
\hline & & 4 & Lack of equipment & Smarghandi 2016 \\
\hline & & 5 & Lack of skilled workforce & Smarghandi 2016 \\
\hline & & 6 & Project location restrictions & Smarghandi 2016 \\
\hline & & 7 & Poor labor productivity & Smarghandi 2016 \\
\hline & & 8 & Design changes & Smarghandi 2016 \\
\hline & & 9 & $\begin{array}{l}\text { The process of utility / } \\
\text { construction land }\end{array}$ & Smarghandi 2016 \\
\hline & & 10 & Flood location & Smarghandi 2016 \\
\hline
\end{tabular}

\subsection{Determining the Number of Respondents}

The minimum number of respondents to answer the questionnaire is needed as a limitation in collecting the required results. According to [25] Respondents' needs can be obtained using the following equation:

$\mathrm{m}=\left(\mathrm{Z}^{\wedge} 2 \times \mathrm{P} \times(1-\mathrm{P})\right) / \varepsilon^{\wedge} 2$

$\mathrm{n}=\mathrm{m} /(1+((\mathrm{m}-1)) / \mathrm{N})$

Where : $\mathrm{N}=84, \varepsilon=0,0, \mathrm{P}=0,5$

$\mathrm{p}$-value $=(1-\varepsilon) / 2=(1-0,05) / 2=0,475$

Based on the $\mathrm{p}$-value, the $\mathrm{Z}$ value is obtained based on the $\mathrm{Z}$ table of normal distribution, $\mathrm{Z}=1,96$ 
International Journal of Engineering Research And Advanced Technology, Vol.7 (4), April -2021

Then the minimum respondent needs are as follows:

$\mathrm{m}=\left(\mathrm{Z}^{\wedge} 2 \times \mathrm{P} \times(1-\mathrm{P})\right) / \varepsilon^{\wedge} 2, \mathrm{~m}=(\llbracket 1,96 \rrbracket \wedge 2 \times 0,5 \times 0,5) / \llbracket 0,05 \rrbracket \wedge 2=0,96 / 0,0025=384,16$

$\mathrm{n}=\mathrm{m} /(1+((\mathrm{m}-1)) / \mathrm{N}), \mathrm{n}=384,16 /(1+((384,16-1)) / 57)=384,16 / 7,72=69,07$

The minimum number of respondents is 69.07 , so the minimum number of respondents is 70 respondents

\subsection{Data Processing Stage}

In the validity test itself, a measure that can show the validity or validity of the instrument. So in testing the validity it refers to an instrument in carrying out its function. The variables obtained from the journal can be published. The process of testing the validity and reliability is carried out using the following tools in the SPSS program, which is a data processing flowchart:

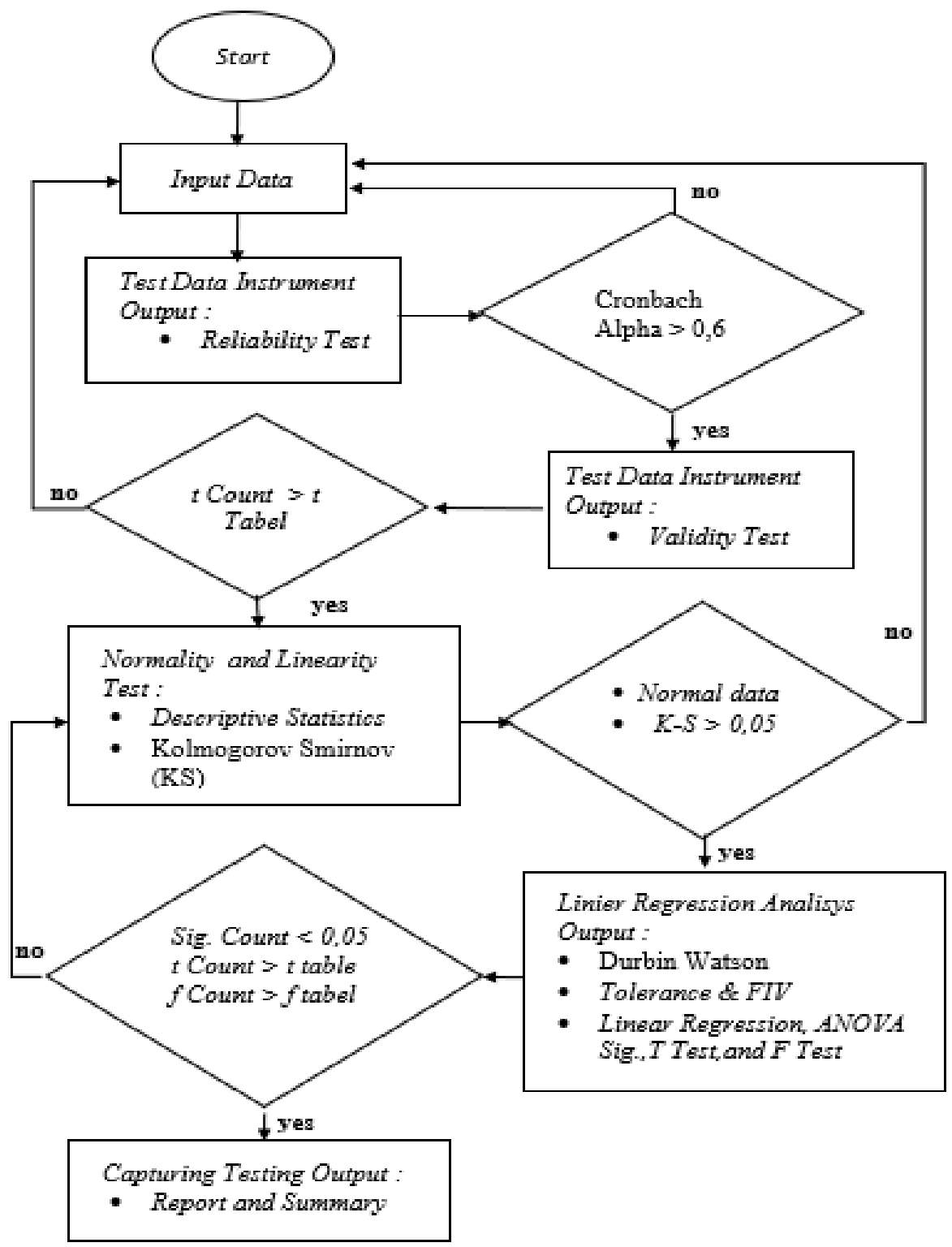

Figure 1.6 Flowchart of SPSS

\subsection{Validity Test and Reliability Test}

From each variable will be tested using SPSS tools, namely the value of the corrected item total correlation (calculated validity) if the value is more than 0.2146 then it can be stated as valid and the value of Cronbach's Alpha (Calculation Reliability). can be stated as realistic, here are the results of data grouping that are both realistic and valid.

Table 1.2 Validity Test Results

\begin{tabular}{|c|c|c|c|}
\hline VARIABLE & ALPHA & VALUE & REMARK \\
\hline Critical Chain Project Management & 0,538 & 0,2146 & Valid \\
\hline
\end{tabular}


International Journal of Engineering Research And Advanced Technology, Vol.7 (4), April -2021

\begin{tabular}{|l|c|c|c|}
\hline Building Information Modeling 4D & 0,430 & 0,2146 & Valid \\
\hline Pekerjaan Basement & 0,490 & 0,2146 & Valid \\
\hline Waktu & 0,624 & 0,2146 & Valid \\
\hline
\end{tabular}

Table 1.3 Reliability Test Results

\begin{tabular}{|l|c|c|c|}
\hline \multicolumn{1}{|c|}{ VARIABLE } & ALPHA & VALUE & REMARK \\
\hline Critical Chain Project Management & 0,861 & 0,700 & reliabel \\
\hline Building Information Modeling 4D & 0,706 & 0,700 & reliabel \\
\hline Pekerjaan Basement & 0,705 & 0,700 & reliabel \\
\hline Waktu & 0,823 & 0,700 & reliabel \\
\hline
\end{tabular}

The results of the average analysis are then compiled into a recapitulation which is presented in the form of sub-factor rankings. The results of the recapitulation of statistical analysis using the average method, more details can be seen in the discussion below

Table 1.4 Recapitulation of Statistical Analysis

\begin{tabular}{|c|c|c|c|}
\hline RANK & & SUB FACTOR & MAIN FACTOR \\
\hline 1 & $\mathrm{X} 1 \_13$ & Identify the project against timing & Buffer Time \\
\hline 2 & X3_12 & Basement design complexity & Implementation \\
\hline 3 & $\mathrm{X} 1 \_14$ & Effect of Project buffer, fedding buffer, buffer resource & Buffer Time \\
\hline 4 & $\mathrm{X} 2 \_3$ & Document design accuracy & Construction Stages \\
\hline 5 & $\mathrm{X} 2 \_2$ & Scheduling and simulation & Construction Stages \\
\hline 6 & $\mathrm{X} 2 \_4$ & Activity logical relationships & Construction Stages \\
\hline 7 & $\mathrm{X} 2 \_5$ & Government policy and support & Construction Stages \\
\hline 8 & X3_11 & Top Down Method & Implementation \\
\hline 9 & X3_9 & Soil conditions & Implementation \\
\hline 10 & X1_15 & Eliminates safety time & Buffer Time \\
\hline 11 & X1_9 & Eliminate Student Syndrome \& Parkinson Law & CCPM \\
\hline 12 & X1_8 & Schedule planning, monitoring, and controlling solution: & CCPM \\
\hline 13 & $\mathrm{X} 1 \_2$ & Minimizing Project Duration & CCPM \\
\hline 14 & $\mathrm{X} 1 \_1$ & Faster turnaround time & CCPM \\
\hline 15 & $\mathrm{X} 2 \_12$ & Equipment modeling in the work environment / site & 4D modeling \\
\hline 16 & X1_6 & Determination of human resources & CCPM \\
\hline 17 & $\mathrm{X} 2 \_13$ & Modeling \& Lay out during the construction process & 4D modeling \\
\hline 18 & X3_6 & Design & Planning \\
\hline 19 & X2_9 & Identify the Project success cycle & Construction Stages \\
\hline 20 & $\mathrm{X} 2 \_14$ & $\begin{array}{l}\text { Modeling and visualization of the significance of environmental } \\
\text { impacts }\end{array}$ & 4D modeling \\
\hline 21 & $\mathrm{X} 1 \_7$ & Schedule planning \& monitoring & CCPM \\
\hline 22 & $\mathrm{X} 1 \_16$ & Risk Management & Buffer Time \\
\hline
\end{tabular}


International Journal of Engineering Research And Advanced Technology, Vol.7 (4), April -2021

\begin{tabular}{|c|c|c|c|}
\hline 23 & $\mathrm{X} 1 \_17$ & Understanding the stages of work & Buffer Time \\
\hline 24 & X3_7 & Construction & Planning \\
\hline 25 & X3_5 & Decisions on design \& construction & Planning \\
\hline 26 & $\mathrm{X} 2 \_10$ & Project activity duration & 4D modeling \\
\hline 27 & X3_1 & Basic Engineering Design & Planning \\
\hline 28 & $\mathrm{X} 2 \_8$ & Determine Project completion constraints & Construction Stages \\
\hline 29 & $\mathrm{X} 2 \_16$ & 4D Project Modeling & 4D modeling \\
\hline 30 & X3_8 & Project environmental conditions & Implementation \\
\hline 31 & X3_10 & Bottom up method & Implementation \\
\hline 32 & X1_11 & Real time Project monitoring & CCPM \\
\hline 33 & $\mathrm{X} 1 \_10$ & Commitment On Time schedule & CCPM \\
\hline 34 & $\mathrm{X} 2 \_1$ & $\begin{array}{l}\text { Effective communication and coordination among the Project } \\
\text { team }\end{array}$ & Construction Stages \\
\hline 35 & $\mathrm{X} 2 \_7$ & Work flow / work stages & Construction Stages \\
\hline RANK & & SUB FACTOR & MAIN FACTOR \\
\hline 36 & $\mathrm{X} 3 \_2$ & Early identification of standardization & Planning \\
\hline 37 & X2_6 & Use of BIM software tools & Construction Stages \\
\hline 38 & X3_3 & Standardization feasibility analysis & Planning \\
\hline 39 & $\mathrm{X} 1 \_3$ & Determine the Project critical path & CCPM \\
\hline 40 & $\mathrm{X} 1 \_5$ & Utilization of CCPM software & CCPM \\
\hline 41 & $\mathrm{X} 1 \_4$ & Steps for design of the CCPM schedule & CCPM \\
\hline 42 & X1_18 & The relationship of each stage of work & Buffer Time \\
\hline 43 & X1_19 & Count \& define buffers & Buffer Time \\
\hline 44 & $\mathrm{X} 2 \_11$ & Simulation of the construction process & 4D modeling \\
\hline 45 & $\mathrm{X} 1 \_12$ & Defines and defines buffers & Buffer Time \\
\hline 46 & $\mathrm{X} 2 \_15$ & Logistics modeling & 4D modeling \\
\hline 47 & Y_2 & Subcontractors & Time \\
\hline 48 & Y_1 & The Weather Is Not Fixed & Time \\
\hline 49 & Y_4 & Lack of Equipment & Time \\
\hline 50 & X3_4 & Building Design \& Building System Management & Planning \\
\hline 51 & Y_7 & Poor Labor Productivity & Time \\
\hline 52 & Y_5 & Lack of Skilled Workforce & Time \\
\hline 53 & Y_6 & Project Location Restrictions & Time \\
\hline 54 & Y_3 & Lack of material & Time \\
\hline 55 & $\mathrm{Y}_{-} 10$ & Location Flood & Time \\
\hline 56 & Y_9 & Utilities Process / Construction Land & Time \\
\hline 57 & Y_8 & Design Change & Time \\
\hline
\end{tabular}

\section{CONCLUSION}


From data analysis using SPSS and after ranking, 10 key success factors for critical chain project management and 4D Building Information Modeling (BIM) were obtained as follows:

1. Identify the project against timing

2. The complexity of the basement design

3. Effect of project buffer, fedding buffer, buffer resource

4. Accuracy of document design

5. Scheduling and simulation

6. Logical relationship activities

7. Government policy and support

8. Top Down Method

9. Soil conditions

10. Eliminates safety time

\section{REFERENCE}

[1] Graham Robinson. (2016). Global construction market to grow $\$ 8$ trillion by 2030: driven by China, US and India. 44(0), 1-3. https://www.databasedanalysis.com/global-construction-perspectives/

[2] Lukas, J. A. (2007). Is your schedule correct?Common scheduling mistakes and how to avoid them. PMI Global Congress 2007-North America, Atlanta, GA. Newtown Square, PA: Project Management Institute

[3] Akram Akhund, M., Raza Khoso, A., Memon, U., Khahro, S. H., \& Scholar, P. (2017). Time Overrun in Construction Projects of Developing Countries. Imperial Journal of Interdisciplinary Research (IJIR, 3(5), 124-129.

[4] Candelario-Garrido, A., García-Sanz-Calcedo, J., \& Reyes Rodríguez, A. M. (2017). A quantitative analysis on the feasibility of 4D Planning Graphic Systems versus Conventional Systems in building projects. Sustainable Cities and Society, 35, 378-384. https://doi.org/10.1016/j.scs.2017.08.024

[5] Moon, H., Kim, H., Kamat, V. R., \& Kang, L. (2015). BIM-Based Construction Scheduling Method Using Optimization Theory for Reducing Activity Overlaps. Journal of Computing in Civil Engineering, 29(3), 04014048. https://doi.org/10.1061/(asce)cp.19435487.0000342

[6] Kerzner, H. (2006). Project Management: A Systems Approach to Planning, Scheduling, and Controlling (Ninth Edit). Canada: John Wiley \& Sond.

[7] Rand, G. K. (2000). Critical chain: The theory of constraints applied to project management. International Journal of Project Management, 18(3), 173-177. https://doi.org/10.1016/S0263-7863(99)00019-8

[8] Goldratt, E., Critical Chain, 1997 (North River Press: Great Barrington, MA)

[9] Sadeghi, M., \& Roghanian, E. (2017). Reliability analysis of a warm standby repairable system with two cases of imperfect switching mechanism. Scientia Iranica, 24(2), 808-822. https://doi.org/10.24200/sci.2017.4063

[10] Rozenes, S., Vitner, G., Spraggett, S., 2004. MPCS: multidimensional project control system. Int. J. Proj. Manag. 22, 109-118

[11] Ahlemann, F., El Arbi, F., Kaiser, M. G., \& Heck, A. (2013). A process framework for theoretically grounded prescriptive research in the project management field. International Journal of Project Management, 31(1), 43-56. https://doi.org/10.1016/j.ijproman.2012.03.008

[12] Horroelen W, Leus R. 2001. On the merit and pitfalls of critical chain scheduling. J Oper Manage. 19:559-577.

[13] Rand, G. K. (2000). Critical chain: The theory of constraints applied to project management. International Journal of Project Management, 18(3), 173-177. https://doi.org/10.1016/S0263-7863(99)00019-8

[14] Horroelen W, Leus R. 2001. On the merit and pitfalls of critical chain scheduling. J Oper Manage. 19:559-577.

[15] Sadeghi, M., \& Roghanian, E. (2017). Reliability analysis of a warm standby repairable system with two cases of imperfect switching mechanism. Scientia Iranica, 24(2), 808-822. https://doi.org/10.24200/sci.2017.4063

[16] Rand, G. K. (2000). Critical chain: The theory of constraints applied to project management. International Journal of Project Management, 18(3), 173-177. https://doi.org/10.1016/S0263-7863(99)00019-8

[17] Newbold RC. 1998. Project management in the fast lane: applying the theory of constraints. New York (NY): St. Lucie Press.

[18] Horroelen W, Leus R. 2001. On the merit and pitfalls of critical chain scheduling. J Oper Manage. 19:559-577.

[19] Jung, Y., \& Joo, M. (2011). Building information modelling (BIM) framework for practical implementation. Automation in Construction, 20(2), 126-133. https://doi.org/10.1016/j.autcon.2010.09.010

[20] Eastman, C. M., and Sacks, R. (2008). "Relative productivity in the AEC industries in the United States for on-site and off-site activities." 
International Journal of Engineering Research And Advanced Technology, Vol.7 (4), April -2021

Journal of Construction Engineering in Management, 134(7), 517-526.

[21] Pazlar, T., \& Turk, Ž. (2008). Interoperability in practice: Geometric data exchange using the IFC standard. Electronic Journal of Information Technology in Construction, 13(March), 362-380.

[22] Asiyanto, Ir, MBA, IPM. 2008. Manajemen Alat Berat Untuk Konstruksi, Penerbit PT. Pradnya Paramita. Jakarta.

[23] Barber, B. (1984): Strong Democracy: Participatory Politics for a New Age. Berkeley: University of California Press

[24] Husin, A. E., Setyawan, T. L., Meidiyanto, H., Kussumardianadewi, B. D., \& Eddy Husin, M. K. (2019). Key success factors implementing BIM based quantity take-off in fit-out office work using relative importance index. International Journal of Engineering and Advanced Technology, 8(6), 986-990. https://doi.org/10.35940/ijeat.F82650.88619

[25] Alaghbari, W., Al-Sakkaf, A. A., \& Sultan, B. (2019). Factors affecting construction labour productivity in Yemen. International Journal of Construction Management, 19(1), 79-91. https://doi.org/10.1080/15623599.2017.1382091 